\title{
ANALISIS KONFLIK DALAM NARASI PERTIKAIAN SARA DAN HAGAR DALAM KEJADIAN 16:1-16
}

\section{Sonny Eli Zaluchu dan Ayu Aditiarani Seniwati}

\author{
Sekolah Tinggi Teologi Baptis Indonesia (STBI), Semarang \\ Jln. Simongan No. 1, Bojongsalaman Selatan Semarang, Jawa Tengah \\ sonnyaluchu@stbi.ac.id
}

\begin{abstract}
Conflict is the central theme in this paper by raising the narrative of the dispute between Sara and Hagar in Genesis 16: 1-16 about the birth of Isaac and Ishmael. This paper aims to discuss the dynamics of the ongoing conflict between Sara and Hagar by relying on narrative and using several contexts close to the central theme. The author uses a narrative approach to discuss and analyze. The dispute between Sara and Hagar was a narrative in the style of the Yahwista writers of Genesis. It can see in the analysis that the narrative writer of the Book of Genesis 16: 1-16 uses conflict as a drive for the plot in composing themes. Abraham did not resolve the dispute. Sara and Hagar could not be reconciled and coexist comfortably. In the end, Hagar expelled by Abraham and went on his way of life. The impact of Abraham's failure to reconcile his two wives led to disharmony of relations between his descendants today in the Middle East. The findings also show that conflict management in this narrative is not visible. Abraham, as the head of the family, could be said to have failed to manage the dynamics of his marriage. But on the other hand, the analysis also concludes that the conflict shows God's intervention to bring about the results of His covenant to Abraham regarding the offspring born from the womb of Sarah, his wife.
\end{abstract}

Keywords: Abraham, Hagar, Sarah, conflict, polygami, Middle-East

\begin{abstract}
Abstrak
Konflik adalah tema sentral di dalam paper ini dengan mengangkat narasi pertikaian antara Sara dan Hagar di dalam Kejadian 16:1-16 di seputar kelahiran Ishak dan Ismael. Paper ini bertujuan membahas dinamika konflik yang berlangsung antara Sara dan Hagar dengan mengandalkan narasi dan menggunakan beberapa konteks yang dekat dengan tema pokok. Penulis menggunakan metode pendekatan naratif untuk melakukan pembahasan dan analisis. Hal ini dilakukan karena pertikaian Sara dan Hagar adalah sebuah narasi yang menjadi gaya para penulis kitab Kejadian dari kelompok Yahwista. Di dalam analisis, penulis narasi Kitab Kejadian 16:1-16 menggunakan konflik sebagai drive bagi plot di dalam merangkai tema. Bahkan ditemukan fakta bahwa konflik tersebut tidak diselesaikan oleh Abraham. Sara dan Hagar tidak dapat hidup berdampingan dengan nyaman dan damai. Pada akhirnya Hagar diusir oleh Abraham dan menempuh jalan hidupnya sendiri. Dampak dari kegagalan Abraham memperdamaikan kedua istrinya berujung pada ketidakharmonisan hubungan di antara keturunannya hari ini di Timur Tengah. Temuan juga memperlihatkan bahwa manajemen konflik di dalam narasi ini tidak terlihat. Abraham, yang memiliki banyak perempuan dalam statusnya sebagai kepala keluarga, gagal mengelola dinamika di dalam
\end{abstract}


pernikahan yang dijalaninya. Akan tetapi di sisi lain, analisis juga menyimpulkan bahwa konflik tersebut memperlihatkan campur tangan Tuhan untuk mewujudkan hasil perjanjianNya kepada Abraham tentang keturunan yang lahir dari rahim Sara.

Kata Kunci: Abraham, Hagar, Sara, konflik, poligami, Timur Tengah

\section{PENDAHULUAN}

Keluarga yang utuh di dalam kebudayaan Timur Tengah, selalu identik dengan kehadiran anak laki-laki yang akan menjadi pewaris, bukan hanya harta, tetapi juga otoritas di dalam keluarga. Itulah sebabnya, perempuan-perempuan yang terikat pernikahan tetapi mandul, kurang begitu dihargai eksistensinya dan cenderung diabaikan. Istilah 'mandul' bukan hanya sekedar menggambarkan kondisi rahim yang tidak dapat dibuahi, tetapi lebih kepada sarkasme sosial masyarakat kuno untuk mendiskreditkan para perempuan tersebut. Anak, khususnya anak laki-laki, tidak hanya diperlukan sebagai penerus garis keturunan melainkan kebanggaan bagi keluarga besar. Di dalam masyarakat Arab misalnya, dikenal istilah 'bin' yang artinya 'anak dari'. Konsep serupa muncul dalam budaya Ibrani menggunakan istilah 'ben'. Identitas dari garis keturunan dibawa langsung oleh anak yang lahir di dalam sebuah keluarga. Maka tidak mengherankan, seorang bapak akan mempersiapkan anak-anak laki-lakinya bukan hanya sebagai pembawa DNA, tetapi pembawa nama yang menggambarkan eksistensi sebuah garis keturunan. Konsep ini sangat kuat mendasari kehidupan perkawinan di dalam keluarga Ibrani sebagaimana digambarkan di dalam Perjanjian Lama (PL). Terlebih jika dikaitkan dengan mandat Ilahi untuk beranak cucu, berkembang biak dan memenuhi bumi (Kejadian 1:28), menurut Perdue, tidak mengherankan jika reproduksi merupakan fungsi yang sangat penting dari keluarga (Kejadian 1:28; 9:1) dan perempuan memainkan peran utama dalam memenuhi maksud tersebut (Kejadian 24:60). ${ }^{1}$

Berdasarkan penjelasan tersebut di atas maka muncul masalah ketika seorang istri sah tidak dapat melahirkan anak bagi suaminya. Di satu sisi, harta dan semua warisan dapat jatuh ke tangan orang lain. Di sisi lain, dan ini yang lebih penting, sebagaimana dijelaskan oleh Packer dkk., masyarakat pada masa itu memandang 
rendah perempuan mandul dan melimpahkan semua penyebab kemandulan itu kepada perempuan (istri). Kemandulan dianggap sebagai sebuah kutukan Allah sehingga seorang perempuan mandul mengalami tekanan baik secara sosial maupun secara psikologis. ${ }^{2}$ Itulah sebabnya menurut Walton, kebiasaan di Timur Tengah masa itu, istri sah menyodorkan budak kepada suaminya untuk melahirkan anak. Tujuan tindakan ini adalah menghadirkan budak sebagai ibu pengganti di dalam keluarga besar sehingga lahir seorang anak atau keturunan yang bisa membela kepentingan istri di dalam kasus kemandulannya. Anak-anak yang dilahirkan oleh para ibu pengganti ini dapat ditunjuk sebagai “anak kandung" istri sah. ${ }^{3}$ Townsend menegaskan bahwa tindakan semacam itu merupakan konsep legal di dalam Alkitab yang bahkan telah menginspirasi banyak perempuan modern dengan kasus kemandulan dewasa ini. Bedanya, ibu pengganti dalam konsep modern diikat di dalam sebuah perjanjian hukum yang kuat. $^{4}$ Sementara pada masa PL, budak perempuan dianggap sebagai properti, sebagai perpanjangan tangan istri sah yang berkuasa atasnya. Di dalam keluarga besar, kedudukan sosial dan legal istri sah, tetap tidak dapat diganggu-gugat. ${ }^{5}$

Konflik seperti ini yang membingkai narasi Kejadian 16:1-16 menyangkut Abraham dan Sara. Usia mereka sudah lanjut dan belum memiliki keturunan. Mustahil melahirkan anak dengan kondisi fisik yang sudah sangat tua dan tidak mendukung. Dengan tegas narasi di PL mencatat, Sara itu mandul, tidak mempunyai anak (Kejadian 11:30). Dampak sosial, dan psikologi dari realitas tersebut sedemikian telah menekan Sara sehingga mencoba mencari jalan penyelesaian melalui pendekatan budaya. Berkatalah Sara kepada Abraham: "Engkau tahu, TUHAN tidak memberi aku melahirkan anak. Karena itu baiklah hampiri hambaku itu; mungkin oleh dialah aku dapat memperoleh seorang anak." Dan Abram mendengarkan perkataan Sara (Kejadian 16:2). Analisis Hamilton menarik. Tidak dapat melihat implikasi jangka panjang dari tindakan tersebut, Abraham mendukung usulan istrinya. Keduanya sudah tinggal di Kanaan sepuluh tahun dan telah berusaha untuk bereproduksi secara normal tetapi gagal (16:3). Maka kehadiran ibu pengganti adalah sebuah solusi akhir. ${ }^{6}$ 
Abraham mengambil Hagar tetap dalam statusnya sebagai budak untuk tujuan memberi anak bagi Sara. Pernikahan keduanya bukan pernikahan resmi sebagaimana adat kebiasaan di masa itu yang menggunakan lamaran dan mas kawin. Kenyataannya, Hagar hamil dan melahirkan seorang anak laki-laki kepada Abraham yang diberi nama Ismael. Konflik mulai terjadi di titik ini. Posisi Sara sebagai istri sah terancam secara domestik karena perangai Hagar yang berubah. Sang gundik memandang rendah akan nyonyanya (Kejadian 16:4) dan terlihat berjuang untuk meraih derajat sosial yang lebih tinggi di hadapan Abraham dan Sara. Pertikaian itu berlangusng terbuka dan terang-terangan antara istri sah dan gundik. Ujungnya, Sara menindas Hagar dan menerapkan otoritasnya kepada perempuan itu. Sebagaimana telah dijelaskan sebelumnya, dalam status sebagai budak, Sara berhak melakukan apa saja kepada Hagar. Sara mendesak Abraham untuk mengambil tindakan. "Penghinaan yang kuderita ini adalah tanggung jawabmu; akulah yang memberikan hambaku ke pangkuanmu, tetapi baru saja ia tahu, bahwa ia mengandung, ia memandang rendah akan aku; TUHAN kiranya yang menjadi Hakim antara aku dan engkau." Kata Abram kepada Sara: "Hambamu itu di bawah kekuasaanmu; perbuatlah kepadanya apa yang kaupandang baik." Lalu Sara menindas Hagar, sehingga ia lari meninggalkannya (Kejadian 16:5-6).

Berdasarkan uraian tersebut di atas dapat ditarik kesimpulan bahwa narasi Kejadian 16:1-16 dapat dilihat sebagai sebuah narasi konflik yang berlangsung antara Sara dan Hagar menyangkut status mereka sebagai istri dan ibu yang melahirkan anak laki-laki bagi Abraham. Oleh sebab itu muncul pertanyaan penelitian, konflik seperti apa yang sebetulnya terjadi di dalam narasi ini? Paper ini bertujuan untuk meneliti lebih lanjut dinamika konflik yang terdapat di dalam narasi Kejadian 16:1-16 khususnya di dalam memetakan pihak-pihak yang terlibat, dinamika yang terjadi dan solusi yang diambil oleh para tokoh di dalam narasi.

\section{METODE PENELITIAN}

Untuk menjawab pertanyaan penelitian, penulis menggunakan pendekatan kualitatif melalui riset pustaka yang memanfaatkan buku, artikel jurnal dan sejumlah commentary. Pembahasan mengikuti patokan penelitian kualitatif sebagaimana 
dijelaskan Zaluchu bahwa penelitian seperti ini dapat dikerjakan dengan studi pustaka dengan analisis yang sifatnya deskriptif. ${ }^{7}$ Penulis mendeskripsikan masalah dengan berpijak pada analisis naratif sebagaimana dimaksud oleh Powell khususnya menyangkut metodologi plot dan konflik. ${ }^{8}$ Semua bahan-bahan tersebut diramu di dalam sistematika yang dimulai dengan penjelasan mengenai hadirnya janji Tuhan kepada Abraham mengenai keturunannya. Selanjutnya, dipaparkan pembahasan mengenai respons Abraham terhadap janji tersebut. Masuknya Sara di dalam konteks narasi yang menyodorkan Hagar sebagai ibu pengganti dijadikan pijakan untuk membangun analisis dan membaca narasi Kejadian 16:1-16 di dalam dua bagian yakni pasca kelahiran Ismael dan pasca kelahiran Ishak. Dengan kata lain, penelitian ini menjelaskan plot yang berkembang di dalam Kejadian 16:1-16 melalui pendekatan konflik sebagai salah satu pendekatan di dalam analisis narasi. Tema konflik itu sebatas dan mencakup tiga hal saja yakni analisis tentang akar konflik, tokoh yang terlibat dan dinamika yang terjadi. Melalui pendekatan ini penulis akan melihat apa yang menjadi tujuan utama dari cerita. Powell mengatakan bahwa keberadaan konflik di dalam sebuah cerita berperan untuk melakukan drive terhadap plot. Bahkan bertujuan untuk membawa pembaca masuk ke dalam pengalaman kisah tersebut dan menciptakan tendensi pembaca. ${ }^{9}$

\section{HASIL DAN PEMBAHASAN}

\section{Abrahamic Covenant}

Kejadian 12:1-3 mencatat peristiwa pertama Allah menyatakan janji-Nya kepada Abraham di usianya yang ke-75 tahun. Di dalam buku Pentateuch - NarasiNarasi Utama Kitab Musa, Zaluchu membagi tiga janji tersebut. Pertama aspek perintah, yang meminta Abraham pergi meninggalkan tempat kelahiran dan semua sanak keluarganya di Ur-Kasdim ke sebuah tempat yang akan ditunjukkan kepadanya. Kedua adalah aspek janji pribadi. Di situ Allah menyatakan janjinya untuk membuat Abraham dan keturunannya menjadi bangsa yang besar dan mendapat kemahsyuran. Sedangkan aspek ketiga menyangkut dampak eksternal di mana Abraham akan menjadi sumber berkat di muka bumi. Esensi tentang keturunan 
DNA terlihat di dalam aspek yang kedua. ${ }^{10}$ Isi kovenan tersebut, sejak semula, sudah menyatakan bahwa Abraham akan memiliki keturunan.

Peneguhan terhadap janji itu mengalami pengulangan. Di dalam Kejadian 12:7 Allah memberikan reminding bahwa negeri yang telah dimasukinya itu akan diberikan kepada Abraham. Setelah berpisah dengan Lot, Allah kembali menyatakan penegasan terhadap kovenan yang telah diikat. Pandanglah sekelilingmu dan lihatlah dari tempat engkau berdiri itu ke timur dan barat, utara dan selatan, sebab seluruh negeri yang kaulihat itu akan Kuberikan kepadamu dan kepada keturunanmu untuk selama-lamanya (Kejadian 13:14-15). Puncaknya adalah pengikatan perjanjian yang disertai dengan tata cara perjanjian yang lazim di masa itu. Tuhan memberikan jawaban yang tegas atas pernyataan Abraham tentang ahli waris. "Engkau tidak memberikan kepadaku keturunan, sehingga seorang hambaku nanti menjadi ahli warisku." Tetapi datanglah firman TUHAN kepadanya, demikian: "Orang ini tidak akan menjadi ahli warismu, melainkan anak kandungmu, dialah yang akan menjadi ahli warismu" (Kejadian 15:3-4).

Kovenan mengenai anak kandung Abraham disahkan di dalam sebuah tradisi Timur Tengah oleh Allah melalui pembelahan binatang. Kata Ibrani untuk kovenan adalah 'berith' yang artinya 'memotong'. ${ }^{11}$ Istilah ini menjelaskan ikat-janji dua belah pihak yang dimateraikan melalui sebuah ritual kuno. Pihak yang mengadakan perjanjian bersama-sama lewat di tengah kedua potongan tersebut sambil menyatakan "biarlah hal seperti ini terjadi padaku jika melanggar perjanjian ini”. Peristiwa tersebut dikatakan sebagai 'memotong perjanjian'. Hal ini menjelaskan bahwa sebuah kovenan disegel melalui sumpah yang kuat dan mengikat. Tidak terdapat ruang untuk pelanggaran. ${ }^{12}$

Yang ingin dijelaskan di sini adalah bahwa sebelum Abraham dan Sara memiliki keturunan sendiri, Allah sudah mendahului menubuatkan melalui janji pribadi tentang keturunan DNA dari mereka berdua. Dalam berbagai kesempatan yang berbeda, Allah mengulang janji itu beberapa kali bukan hanya sekedar meyakinkan Abraham. Yang dibutuhkan Allah sebetulnya adalah kesediaan Abraham untuk melihat semua janji tersebut di dalam perspektif Tuhan. Bukan berpijak pada realitas empirik. Pijakan pada kenyataan akan melemahkan 
kepercayaan dan ikatan terhadap janji Tuhan dan membuka pintu yang sangat lebar bagi hadirnya pertimbangan akal sehat.

\section{Menggenapi Kovenan dengan Usaha Manusia}

Bukannya memenuhi standar Tuhan untuk bertahan di dalam janji, Abraham justru menerima kesepakatan istrinya untuk menggenapi janji tersebut dalam perspektif manusiawi. Indera dan akal sehat Abraham berjalan mendahului imannya, bahwa dengan mengambil Hagar sebagai istri, kovenan dengan Elohim tergenapi. Tawaran yang diusulkan Sara adalah pertimbangan yang sangat masuk akal dan sesuai dengan konteks budaya Timur Tengah. Keputusan tersebut diperbolehkan secara hukum, di mana seorang istri yang mandul dapat memberikan hambanya sebagai gundik atau istri kedua bagi suaminya untuk tujuan memperoleh anak. Anak yang lahir dari seorang hamba secara hukum dapat diakui sebagai anak dari istri yang sah. ${ }^{13}$ Dengan kata lain, konsep Sarah merupakan produk budaya tentang kehadiran ibu pengganti di dalam perkawinan berkasus (Sarah mandul).

Jika dianalisis, cara yang ditempuh Abraham dan Sara untuk bereproduksi dan mendapatkan keturunan adalah pendekatan manusiawi. Akan tetapi langkah tersebut bukanlah cara yang Tuhan kehendaki. Konsep perjanjian Allah kepadanya adalah keturunan dari Sara, bukan dari Hagar. Itulah sebabnya muncul istilah anak perjanjian dan anak kedagingan. Persepektif Tuhan tentang keturunan adalah anak perjanjian, bukan anak yang diperanakkan dalam kedagingan. Kendatipun Tuhan belum menjelaskan secara rinci mengenai konsep "keturunanmu" seharusnya Abraham lebih memilih menaati Tuhan daripada mendengarkan Sara. Terlihat bahwa level iman Abraham masih belum tiba pada titik puncak yang menjadi standar Tuhan.

Standar iman tersebut baru dicapai Abraham di dalam Kejadian 22:1-18 melalui perintah Tuhan untuk mempersembahkan Ishak sebagai 'anak perjanjian' menjadi korban bakaran di atas gunung. Respons yang berbeda diperlihatkan Abraham. Tanpa menunda dan tanpa keraguan, Abraham memboyong Ishak menuju altar pengorbanan dari Beer-sheva ke Gunung Moria dalam perjalanan sejauh 300 km. Hasilnya adalah pernyataan yang sangat spesifik dari Tuhan. "Aku bersumpah demi diri-Ku sendiri - demikianlah firman TUHAN - :Karena engkau telah berbuat 
demikian, dan engkau tidak segan-segan untuk menyerahkan anakmu yang tunggal kepada-Ku, maka Aku akan memberkati engkau berlimpah-limpah dan membuat keturunanmu sangat banyak seperti bintang di langit dan seperti pasir di tepi laut, dan keturunanmu itu akan menduduki kota-kota musuhnya. Oleh keturunanmulah semua bangsa di bumi akan mendapat berkat, karena engkau mendengarkan firman-Ku" (Kejadian 22:16-18). ${ }^{14}$

Apabila persembahan Ishak di Gunung Moria dijadikan patokan di dalam mengukur kadar iman Abraham, maka akan terlihat dua kontras. Sebelum Ishak lahir, Abraham terlihat masih dikontrol oleh akal sehatnya dan usaha-usaha manusiawi di dalam memahami maksud Allah. Sebaliknya, sejak dari peristiwa Moria, Abraham seperti mengalami breakthrough di dalam caranya terhubung dan memahami Tuhan. Kedua peristiwa tersebut menarasikan naiknya level iman Abraham. Terbukti dari perkataannya tentang domba korban yang ditanyakan Ishak saat mendaki ke puncak Moria. Kalimat 'Allah menyediakan' merupakan perspektif baru di dalam spektrum kepercayaan Abraham kepada Elohim. ${ }^{15}$

\section{Pasca Kelahiran Ismael}

Sara tidak pernah berpikir bahwa keinginannya untuk memperoleh anak melalui Hagar justru berbalik menjadi serangan terhadap eksistensinya sebagai istri sah. Berawal dari Hagar mengandung, perempuan Mesir ini mulai memandang rendah nyonyanya. Kata Ibrani yang dipakai penulis teks Kejadian adalah qâlal yang artinya membenci, menghina dan mengutuk. ${ }^{16}$ Dengan kata lain, Hagar memandang Sara dengan mata penuh ejekan dan penghinaan. Perempuan ini melupakan status sosialnya di dalam kemah Abraham sebagai gundik dan budak. Bahan ekstra biblikal memberi kesaksian bahwa karakter Hagar tersebut dilatarbelakangi oleh asal usulnya sebagai seorang putri Firaun di Mesir. Sang gundik bukan perempuan biasa yang harus menghadap tuannya dengan kepala tertunduk. Asal-usul tersebut menjadi argumen penguat yang melatarbelakangi perubahan sikapnya kepada Sara. ${ }^{17}$

Sara yang merasa terancam dengan perubahan sikap itu menyadari bahwa Hagar adalah sebuah ancaman domestik yang tidak hanya menggoyang kedudukannya sebagai istri resmi. Sebagai ibu yang seharusnya melahirkan ahli 
waris dinasti, pengaruhnya akan meluas di dalam seluruh perkemahan, termasuk di mata para hamba. Pada masa itu, secara hukum ahli waris akan jatuh kepada anak laki-laki tertua. ${ }^{18}$

Sikap dan respons Sara diungkapkan sangat praktis di dalam narasi. Sara berbalik menindas hambanya itu. Kata kerja yang dipakai untuk menindas adalah '̂nâh yang artinya mengata-ngatai dengan keras, memperlakukan dengan kasar, membuat menderita melalui berbagai hal dan menekan di dalam berbagai aspek. ${ }^{19}$ Dengan kata lain, Sara benar-benar memperlakukan Hagar sebagai budak yang tidak memiliki harkat dan status apapun. Tidak kuat menanggung semua beban dan tekanan tersebut di dalam kondisi hamil, Hagar melarikan diri dari perkemahan.

Kemampuan para penulis kitab Kejadian terlihat di dalam narasi ini. Sebuah jeda dituliskan melalui kisah perjumpaan Hagar dengan malaikat Tuhan di dalam pelariannya. Perjumpaan tersebut merupakan sebuah intervensi ilahi bahwa Hagar berada di dalam perhatian Tuhan dan tidak dibiarkan menderita. Saat beristirahat di sebuah mata air, malaikat Tuhan menyapanya sebagai 'hamba Sara'. "Hagar, hamba Sara, dari manakah datangmu dan ke manakah pergimu?" Jawabnya: "Aku lari meninggalkan Sara, nyonyaku (Kejadian 16:8). Sapaan tersebut hendak mengingatkan Hagar bahwa seperti apapun situasinya, kapasitas Hagar adalah seorang budak perempuan yang telah terikat selamanya. Ego perempuan yang over expectation ini terlihat dikembalikan pada tempat di mana seharusnya berada. Keputusannya jelas, Hagar harus kembali ke perkemahan dan harus siap menghadapi semua perilaku Sara kepadanya. ${ }^{20}$ Sebagai hasil dari harga penderitaan yang akan dialaminya, Hagar mendapatkan janji Tuhan. Aku akan membuat sangat banyak keturunanmu, sehingga tidak dapat dihitung karena banyaknya. "Selanjutnya kata Malaikat TUHAN itu kepadanya: "Engkau mengandung dan akan melahirkan seorang anak laki-laki dan akan menamainya Ismael, sebab TUHAN telah mendengar tentang penindasan atasmu itu" (Kejadian 16:10-11).

\section{Pasca Kelahiran Ishak}

Tuhan memperhatikan Sara sehingga akhirnya mengandung di usia lanjut. Terlihat bahwa penulis ingin memberitahukan pembaca bahwa kemandulan Sara 
bukanlah penyakit atau kutukan tetapi penundaan. Sara melahirkan anak laki-laki yang diberi nama Ishak. Pada waktu itu Abraham telah berusia 100 tahun. Di titik ini, semua perjanjian Tuhan kepada Abraham akhirnya menjadi terang benderang. Anak yang dimaksud di dalam perjanjian bukanlah anak kedagingan sebagaimana diperolehnya dari Hagar, melainkan anak yang lahir dari rahim istrinya sendiri. Kebingungan dan bahkan keraguan manusiawinya terhadap semua pernyataan Tuhan selama ini pada berbagai kesempatan akhirnya sirna. Bukti dari kovenan mulai digenapi satu demi satu.

Akan tetapi, muncul satu persoalan baru. Di dalam perkemahan terdapat dua perempuan yang sama-sama memberikan anak laki-laki kepada Abraham. Unsur kompetisi terlihat di antara kedua perempuan tersebut. ${ }^{21}$ Siapakah yang akan menjadi pewaris utama? Siapakah yang akan menjadi pemegang otoritas di dalam keluarga besar? Kedua pertanyaan tersebut mendesak untuk dijawab oleh Abraham. Inisiatifnya datang dari Sara. Pada perayaan penyapihan Ishak, Sara meminta Abraham untuk mengusir Hagar dan Ismael. Berkatalah Sara kepada Abraham: "Usirlah hamba perempuan itu beserta anaknya, sebab anak hamba ini tidak akan menjadi ahli waris bersama-sama dengan anakku Ishak" (Kejadian 21:10). Alasan di balik pengusiran ini sangat transparan. Hanya boleh ada satu bintang di dalam sebuah dinasti. Sebelum semuanya terlambat dan menimbulkan perang saudara, Sara mendahului dengan klaim bahwa anaknya adalah pewaris satu-satunya. Hamilton mengatakan bahwa Abraham dibuat tidak berdaya karena rencana tersebut ikut direstui Elohim karena memang demikianlah rencana-Nya ${ }^{22}$ Tetapi Allah berfirman kepada Abraham: "Janganlah sebal hatimu karena hal anak dan budakmu itu; dalam segala yang dikatakan Sara kepadamu, haruslah engkau mendengarkannya, sebab yang akan disebut keturunanmu ialah yang berasal dari Ishak. Tetapi keturunan dari hambamu itu juga akan Kubuat menjadi suatu bangsa, karena iapun anakmu" (Kejadian 21:12-13). Pasca kelahiran Ishak, konflik antara kedua perempuan tersebut memuncak pada pengusiran Hagar dan Ismael. ${ }^{23}$ Bagaimana dengan Ismael?

Afdilah di dalam papernya mengatakan bahwa setelah peristiwa pengusiran Hagar dan Ismael, Abraham mengajak keduanya menuju suatu tempat yang tidak dikenal dan selanjutnya disebut Bakka (Mekkah). ${ }^{24}$ Hal ini tidaklah sama dengan apa 
yang dikatakan Alkitab, bahwa Ismael tinggal di padang gurun Paran, beristri seorang perempuan Mesir dan menjadi seorang pemanah (Kejadian 21:20-21). Halim menjelaskan di dalam perspektif teologi Islam bahwa dalam sebuah tradisi Yahudi, Abraham tetap menjalin hubungan dengan Ismael di mana agama Yahudi sendiri pun tidak mengetahui sama sekali jika Abraham dan Ismael membangun dan memurnikan Ka'bah, serta menetapkan Ismael dan keturunannya di sana. ${ }^{25}$

\section{KESIMPULAN}

Akhir dari plot narasi di dalam Kejadian 16:1-16 adalah digenapinya kovenan Elohim dengan Abraham. Semua konflik yang melibatkan para tokoh mengarah pada satu titik bahwa pada akhirnya, desain Tuhan yang harus diterapkan dan berhasil. Rencana manusia dan semua upayanya tidak akan mampu melebih rancangan Tuhan. Jika melihat benang merah dari setiap narasi, semua setting, plot dan conflict yang menjadi konten peristiwa, berjalan di dalam skenario para penulis Yahista untuk mengarahkan pembaca pada kesimpulan akhir, bahwa ketetapan Tuhan-lah yang akan terjadi.

Narasi di dalam Kejadian 16:1-16 juga memperlihatkan sebuah dinamika konflik yang hidup. Usaha ini terlihat dari kemampuan para sastrawan Timur Tengah membawa pembaca kepada titik akhir yakni kovenan. Dalam kelompok empat penulis Pentateukh, para penulis dari kelompok Yahwista dikenal dengan kemampuan menciptakan alur cerita yang hidup dan mampu membuat karya sastra menjadi indah. Alurnya bergerak mengalir dan sangat dinamis. Tulisan-tulisan mereka digemari karena mengandung tema-tema menarik yang menampilkan pergolakan para tokoh. ${ }^{26}$ Menyangkut kisah seputar kemandulan Sara, kelahiran Ismael dan Ishak, peran dan pergolakan para tokoh di dalam cerita sangat kental.

Pembaca masa kini yang dipengaruhi oleh aspek etika dan moralitas pasti tidak akan menyetujui tindakan pengusiran Hagar dan Ismael karena terkesan tidak manusiawi. Terlebih lingkungan tempat mereka berada adalah padang gurun. Tetapi inilah yang menjadi gaya dari para penulis Yahwista itu. Mereka mengabaikan aspek penilaian masa kini dan berusaha menarik pembaca masuk ke dalam teks untuk mengalami sesuatu. Terlebih, kisah ini dituturkan bukan untuk kepentingan dan 
alasan moralitas melainkan di dalam konsep penggenapan kovenan. Konflik menjadi bagian dari skenario yang tanpa sadar menggiring pembaca untuk tiba pada kesimpulan, sebagaimana dituntut kepada Abraham, mempercayai janji Tuhan apapun situasinya.

Dampak lain dari konflik ini adalah peliknya perdamaian di antara keturunan Abraham masa kini di Timur Tengah. Keturunan Abraham, terbagi ke dalam penganut tiga agama monoteis (Yahudi, Kristen dan Islam). Keturunan itu hingga kini sangat sulit mempertahankan perdamaian dan sepakat secara politik serta kewilayahan. Masing-masing saling memposisikan diri sebagai pewaris yang sah dan utama di dalam dinasti. Bahkan setiap tradisi agama memiliki versinya sendiri seputar konflik yang dibahas di dalam paper ini. Sebagaimana dijelaskan sebelumnya bahwa di dalam sebuah dinasti di Timur Tengah, pewaris utama berhak atas double portion warisan dan menjadi kepala dari seluruh keluarga yang memiliki fungsi kontrol. Dengan kata lain, konflik di Timur Tengah merepresentasikan apa yang dulu pernah terjadi di dalam konflik Sara dan Hagar, dan yang tak pernah selesai, mengenai isu hegemoni, siapa yang menguasai siapa, dan siapa yang tunduk pada kekuasaan siapa. Dinamika inilah yang terlihat di dalam generasi demi generasi keturunan Abraham di Timur Tengah. Akar utama dari pertikaian Sara dan Hagar adalah siapa yang memperoleh kedudukan dan hak waris. Inilah yang kemudian menjadi isu penting Timur Tengah mengenai siapa yang berhak disebut keturunan Abraham dan menguasai tanah Kanaan.

Di sisi lain, narasi juga mengangkat masalah domestik dan rumah tangga akibat keterlibatan perempuan lain di dalam keluarga. Sistem poligami di dalam PL terjadi karena alasan-alasan tertentu. Khusus di dalam narasi Kejadian 16:1-16 poligami terjadi karena kemandulan Sara. Status pernikahan tersebut bukanlah disebut pernikahan resmi karena tujuannya, suami (Abraham) menikahi budak (Hagar) atas persetujuan isterinya (Sara) untuk tujuan sebagai ibu pengganti. Hagar tetap di dalam statusnya sebagai budak. Bukan menggantikan status fungsional sebagaimana istri sah. Persoalan terjadi ketika Hagar berusaha merebut kedudukan yang lebih tinggi akibat keunggulannya dari istri sah melalui kelahiran anak laki-laki pertama. Sehingga terjadilah tarik-menarik kepentingan. Jika tidak diikuti oleh 
kepemimpinan yang kuat, maka keluarga, di dalam kasus seperti ini, akan mengalami konflik berkepanjangan dan destruktif. Oleh sebab itu, poligami di dalam teologi Kristiani dianggap sebagai produk PL yang discontinue.

Hal berikutnya yang dapat disimpulkan di dalam analisis ini adalah mengenai penyelesaian konflik. Meskipun Alkitab tidak membeberkan adanya narasi perdamaian antara Sara dan Hagar, sumber-sumber non biblikal menyebut bahwa Abraham ternyata masih memelihara hubungan dengan istri-istri (gundiknya) dan keturunannya yang lain. Tidak terlihat adanya usaha Abraham untuk menyelesaikan pertikaian yang ada, dan cenderung menyelesaikan konflik dengan tindakan pemisahan (separation). Ini bukanlah teladan yang baik di dalam kerangka penyelesaian masalah.

Menggunakan teknik naratif untuk menelaah kisah-kisah di dalam PL dapat menolong pembaca modern memasuki alam berpikir penulis dan tujuan-tujuan yang hendak dicapainya. Terlihat di dalam kisah kelahiran Ishak, penulis hendak membawa pembaca untuk memahami cerita itu dari sudut pandang kovenan yang merupakan mata rantai panjang sebuah rencana besar Allah bagi dunia, dengan Yesus Kristus sebagai proyeksi final.

\section{Endnotes:}

\footnotetext{
${ }^{1}$ Leo G Perdue, "The Israelite and Early Jewish: Summary and Conclusions," in Families in Ancient Israel, ed. Don S. Browning and Ian S. Evison (Louisville, Kentucky: Westminster John Knox Press, 1997).

${ }^{2}$ J.I. Packer, Merril C. Tenney, and Jr. William White, Ensiklopedi Fakta Alkitab - Bible Almanac 2, 3rd ed. (Malang: Gandum Mas, 2014), 910-11.

3 John H. Walton, Victor H. Matthews, and Mark C. Chavalas, The IVP Bible Background Commentary - Old Testament (Downer s Grove, Illionis: IVP Academic, 2000), 49.

${ }^{4}$ Margaret D. Townsend, "Surrogate Mother Agreements: Contemporary Legal Aspects of a Biblical Notion.," University of Richmond Law Revisew. University of Richmond 16, no. 2 (1982): 467-83.

${ }^{5}$ Walton, Matthews, and Chavalas, 49.

${ }^{6}$ Victor P. Hamilton, Handbook on the Pentateuch (Grand Rapids, Michigan: Baker Academic, 2008), 90.

7 Sonny Eli Zaluchu, "Strategi Penelitian Kualitatif Dan Kuantitatif Di Dalam Penelitian Agama," Evangelikal: Jurnal Teologi Injili Dan Pembinaan Warga Jemaat 4, no. 1 (January 31, 2020): 2838, https://doi.org/10.46445/ejti.v4i1.167.

${ }^{8}$ Mark Allah Powell, "Narrative Criticism," in Hearing the New Testament, ed. Joel B. Green, 2nd ed. (Grand Rapids, Michigan: Eerdmans Publishing Co., 2010), 239-55.

9 Powell, "Narrative Criticism," 245.

${ }^{10}$ Sonny Eli Zaluchu, Pentateuch - Narasi Narasi Utama Kitab Musa, 1st ed. (Semarang: Golden Gate Publishing, 2020), 75.
} 
11 Anselm C. Hagedorn, "The Covenant Formula: An Exegetical and Theological Investigation," Journal of Jewish Studies 51, no. 1 (2000): 326-27, https://doi.org/10.18647/2285/jjs-2000.

${ }^{12}$ Zaluchu, Pentateuch - Narasi Narasi Utama Kitab Musa, 26; Mike Beaumont, The New Lion Bible Encyclopedia (England: Lion Hudson plc, 2012), 132.

13 Martina Mamus, "Hagar Perempuan Merdeka: Inspirasi Bagi Perjuangan Kesetaraan Gender," Melintas 33, no. 3 (2018): 279-301, https://doi.org/10.26593/mel.v33i3.3073.279-301.

14 Konrad Schmid, “Abraham's Sacrifice: Gerhard von Rad's Interpretation of Genesis 22," Interpretation- Journal of Bible and Theology 62, no. 3 (2008): 268-75, https://doi.org/10.1177/002096430806200305.

15 Álvaro Silva, "The Invention of Religion: Faith and Covenant in the Book of Exodus," Mayéutica 44, no. 97 (2018): 216-17, https://doi.org/10.5840/mayeutica2018449710.

16 John Joseph Owens, Analytical Key to the Old Testament. Volume 1. (Grand Rapids, Michigan: Baker Books, 1998), 58; James Strong, "A Concise Dictionary of the Words in the Hebrew Bible," in Strong's Exhaustive Concordance of the Bible (Iowa Falls: World Bible Publishers, 1986).

${ }^{17}$ Yossi Maimon, Discover the Land of Israel - Volume Two (Israel: Chaim Mazo, 2015), 28; Zaluchu, Pentateuch - Narasi Narasi Utama Kitab Musa, 77.

${ }^{18}$ Stephen M. Miller, Panduan Lengkap Alkitab, ed. Windiasih Sairoen, Ellia Erliani, and Rika Uli Napituulu-Simorangkir, 1st ed. (Jakarta: BPK Gunung Mulia, 2020), 11-12.

${ }^{19}$ Owens, Analytical Key to the Old Testament. Volume 1., 59; Strong, "A Concise Dictionary of the Words in the Hebrew Bible," 137.

${ }^{20}$ E. G. Means, "Genesis, and: Hagar and Sarai, and: Remembering Being Is Birth, and: Natality," Colorado Review 44, no. 1 (2017): 140-45, https://doi.org/10.1353/col.2017.0027.

21 Carroll Stuhlmueller, "The Women of Genesis," Bible Today 28 (1990): 347-52, http://search.ebscohost.com/login.aspx?direct=true\&db=oah\&AN=OTA0000039298\&site=eds-live.

22 Victor P. Hamilton, Handbook on the Pentateuch (Grand Rapids, Michigan: Baker Academic, 2008), 91-92.

${ }^{23}$ André Wénin, "Sarah, Hagar and Abraham: A Narrative and Contextual Approach of Gn 16: 1-6," Revue Theologique de Louvain, 2001, https://doi.org/10.2143/rtl.32.1.2017507.

${ }^{24}$ Muhammad Afdillah, "Teologi Ibrahim Dalam Perspektif Agama Yahudi, Kristen, Dan Islam," Kalimah 14, no. 1 (2016): 97, https://doi.org/10.21111/klm.v14i1.363.

25 Ilim Abdul Halim, “Agama Yahudi Sebagai Fakta Sejarah Dan Sosial Keagamaan,” Religious: Jurnal Studi Agama-Agama Dan Lintas Budaya 1, no. 2 (2017): 135, https://doi.org/10.15575/rjsalb.v1i2.1392.

${ }^{26}$ YM Seto Marsunu, Pengantar Ke Dalam Taurat (Yogyakarta: Kanisius, 2017), 14-15.

\section{DAFTAR PUSTAKA}

Afdillah, Muhammad. "Teologi Ibrahim Dalam Perspektif Agama Yahudi, Kristen, Dan Islam.” Kalimah 14, no. 1 (2016): 97. https://doi.org/10.21111/klm.v14i1.363.

Beaumont, Mike. The New Lion Bible Encyclopedia. England: Lion Hudson plc, 2012.

Hagedorn, Anselm C. "The Covenant Formula: An Exegetical and Theological 
Investigation." Journal of Jewish Studies 51, no. 1 (2000): 326-27. https://doi.org/10.18647/2285/jjs-2000.

Halim, Ilim Abdul. "Agama Yahudi Sebagai Fakta Sejarah Dan Sosial Keagamaan.” Religious: Jurnal Studi Agama-Agama Dan Lintas Budaya 1, no. 2 (2017): 135. https://doi.org/10.15575/rjsalb.v1i2.1392.

Hamilton, Victor P. Handbook on the Pentateuch. Grand Rapids, Michigan: Baker Academic, 2008.

Maimon, Yossi. Discover the Land of Israel - Volume Two. Israel: Chaim Mazo, 2015.

Mamus, Martina. "Hagar Perempuan Merdeka: Inspirasi Bagi Perjuangan Kesetaraan Gender." Melintas 33, no. 3 (2018): 279-301. https://doi.org/10.26593/mel.v33i3.3073.279-301.

Marsunu, YM Seto. Pengantar Ke Dalam Taurat. Yogyakarta: Kanisius, 2017.

Means, E. G. "Genesis, and: Hagar and Sarai, and: Remembering Being Is Birth, and: Natality." Colorado Review 44, no. 1 (2017): 140-45. https://doi.org/10.1353/col.2017.0027.

Miller, Stephen M. Panduan Lengkap Alkitab. Edited by Windiasih Sairoen, Ellia Erliani, and Rika Uli Napituulu-Simorangkir. 1st ed. Jakarta: BPK Gunung Mulia, 2020.

Owens, John Joseph. Analytical Key to the Old Testament. Volume 1. Grand Rapids, Michigan: Baker Books, 1998.

Packer, J.I., Merril C. Tenney, and Jr. William White. Ensiklopedi Fakta Alkitab Bible Almanac 2. 3rd ed. Malang: Gandum Mas, 2014.

Perdue, Leo G. "The Israelite and Early Jewish: Summary and Conclusions." In Families in Ancient Israel, edited by Don S. Browning and Ian S. Evison. Louisville, Kentucky: Westminster John Knox Press, 1997.

Powell, Mark Allah. "Narrative Criticism." In Hearing the New Testament, edited by Joel B. Green, 2nd ed., 239-55. Grand Rapids, Michigan: Eerdmans Publishing Co., 2010.

Schmid, Konrad. “Abraham's Sacrifice: Gerhard von Rad's Interpretation of Genesis 
22." Interpretation- Journal of Bible and Theology 62, no. 3 (2008): 268-75. https://doi.org/10.1177/002096430806200305.

Silva, Álvaro. "The Invention of Religion: Faith and Covenant in the Book of Exodus." Mayéutica 44, no. $97 \quad$ (2018): 216-17. https://doi.org/10.5840/mayeutica2018449710.

Strong, James. "A Concise Dictionary of the Words in the Hebrew Bible." In Strong's Exhaustive Concordance of the Bible. Iowa Falls: World Bible Publishers, 1986.

Stuhlmueller, Carroll. "The Women of Genesis." Bible Today 28 (1990): 347-52. http://search.ebscohost.com/login.aspx?direct=true \&db=oah\&AN=OTA0000 039298\&site=eds-live.

Townsend, Margaret D. "Surrogate Mother Agreements: Contemporary Legal Aspects of a Biblical Notion." University of Richmond Law Review. University of Richmond 16, no. 2 (1982): 467-83.

Walton, John H., Victor H. Matthews, and Mark C. Chavalas. The IVP Bible Background Commentary - Old Testament. Downer s Grove, Illionis: IVP Academic, 2000.

Wénin, André. "Sarah, Hagar and Abraham: A Narrative and Contextual Approach of Gn 16: 1-6." Revue Theologique de Louvain, 2001. https://doi.org/10.2143/rtl.32.1.2017507.

Zaluchu, Sonny Eli. Pentateuch - Narasi Narasi Utama Kitab Musa. 1st ed. Semarang: Golden Gate Publishing, 2020.

. "Strategi Penelitian Kualitatif Dan Kuantitatif Di Dalam Penelitian Agama." Evangelikal: Jurnal Teologi Injili Dan Pembinaan Warga Jemaat 4, no. 1 (January 31, 2020): 28-38. https://doi.org/10.46445/ejti.v4i1.167. 